\title{
AT THE THRESHOLD OF THE FOURTH INDUSTRIAL REVOLUTION: WHO GETS WHO LOSES
}

\author{
Ivana Kraftová, Iveta Doudová, Radim Miláček
}

\section{Introduction}

In July 2014, the German agency GTAI (Germany Trade \& Invest) released a comprehensive document named Industry 4.0 with a subtitle, Smart Manufacturing for the Future, identifying Germany as a potential global leader in digital economy development based on the definition of Industry 4.0. (MacDougall, 2014) When the elements of electronics and information technology in industrial processes were used in the late 1960s, the imaginary door opened to the start of the industrial revolution, the fourth in row.

In connection with this new phenomenon, Kondratieff's theory of long cycles is often mentioned. Already in 1943, however, Garvy pointed out the need for a more comprehensive distinction between the different phases of the capitalist economy and states that "... the curve of the capitalist evolution would ... certainly more irregular than Kondratieff's long cycles." (Garvy, 1943, p. 220) The Russian authors link the Kondratief's theory with the cybernetic revolution, the final stage of which known as the phase of self-regulating systems they predict for the years 2030-2060. At the same time, they emphasize the combination of technologies and introduce the acronym MANBRIC-technologies (medico-additive-nano-bio-robot-info-cognitive technologies) (Grinin, Grinin, \& Korotayev, 2017).

Each of the previous industrial revolutions was characterized by a central element that shifted significantly technological production base that this jump could no longer be presented as a gradual, continuous evolution. The beginning of the First Industrial Revolution dates back to the end of the 19th century, its origins are connected with the United Kingdom and it marks the "century of steam". After about a hundred years, it is followed by the Second Industrial Revolution, bringing the age of electricity, as well as major changes in the organization of production, the internationalization of production relations, changes in the economic position of Europe and the USA, to be overcome at the beginning of the second half of the 20th century by the Third Industrial Revolution, known as the scientific and technical revolution for close connection of production with scientific research results. Even shorter time was enough for the academic and industrial circles to start talking about the Fourth Industrial Revolution (4IR) based on the digitization of production processes, more precisely connecting the virtual world to the real world, with trends heading towards CyberPhysical Production Systems (CPPS) and Internet of Things (IoT). The technological nature of the Fourth Industrial Revolution is also stressed by Chinese authors who see a broader prospect for future economic development in connecting the digital, physical and biological technologies. (Li, Hou, \& Wu, 2017)

The introduction of artificial intelligence (i.e. artificial intelligence revolution) creates, on the one hand, tremendous opportunities for new products and services and, on the other hand, it is linked to the dangers of rising unemployment and greater wealth inequalities. (Makridakis, 2017) Sociological aspects of the problem are also dealt with by Kamensky (2017), who describes the social paradoxes of Industry 4.0. It is not just the introduction of digital technologies into administrative management processes, which in the area of contact with the customer, admittedly, tend to somewhat depersonalize business. This fact is accepted for example by most top executives of Czech companies - according to the latest survey by PricewaterhouseCoopers full 53\% - at the same time, they are more interested in risk management and data security issues (PwC, 2017). 
Each of the previous industrial revolutions have had a major impact on the structure of the economic sectors and industries, as well as each affecting the positions of countries in the international division of labor, changing their degree of competitiveness as a whole as well as individual industry actors.

The question arises as to how the world's most important economies stand at the threshold of the Fourth Industrial Revolution but also how the economies of Central and Eastern Europe (CEE), i.e. the Czech Republic, Hungary, Poland, Slovakia, Estonia, Lithuania and Latvia stand. After all, as from this comparison appears, the Czech economy, in which works the National Convention on the European Union, coordinated by the Office of the Government of the Czech Republic in its conclusions of December 2016, states that although manufacturing industry is the epicenter of the Fourth Industrial Revolution, its scope is so extensive that we need to talk not only about Industry 4.0 but about Society 4.0. Emphasis is also placed on the emphasis in the area of security in its entirety (the National Convention of the EU, 2016), because this opportunity is "balanced" by a threat that calls for prudence, advance deliberate elimination of possible negative consequences.

The aim of this article is to present the results of the research that focused on comparing the positions of the selected group of countries at the threshold of the Fourth Industrial Revolution in terms of their performance and competitiveness after the third wave of globalization that occurred in connection with significant socio-economic changes in the 1990 s of the 20th century.

The sample of analyzed countries consists of two main groups - a group of six major economies in the world (of which 5 are traditional market economies plus China) and a group of seven European countries that have transformed their national economy into market after 1990. Every industrial revolution hit the whole world, with varying intensity and timing. We can assume that in the Fourth Industrial Revolution the big high performing word's economies will play an important role. Does that mean that smaller economies are a priori outsiders? With regard to the industrial revolution, attention must be paid to industry, especially to manufacturing, although its share in the creation of gross value added in advanced economies is by no means dominant, as well as the information and communication technologies (ICT), which in the revolution based on digitization will undoubtedly play the first violin.

Three main research questions have been identified:

i) There are differences in localization, respectively in the concentration of manufacturing and the ICT industries defined, i.e. differently for large, differently for newly transformed CEE economies in the reference period?

ii) How do the development of ICT industries in both selected groups of countries differ in terms of their share of gross value added and in terms of growth?

iii) What is the difference in the development of export capability in the area of ICT in the monitored countries; is this area at the threshold of the Fourth Industrial Revolution their comparative advantage?

\section{Literature Review}

Structure of economic sectors, industries, or disciplines have long been an important element in the performance assessment of national economies (Fisher, 1939; Marais, 1981; Saboniene, 2010), as well as the individual European regions whose evolution is observed and argued by the process of ß-convergence (Paci, 1997). Zdražil and Applová (2016) identify even across the EU $\sigma$-convergence in terms of gross domestic product (GDP) growth, productivity and employment, although it does not confirm this at the national level for the V4 countries as part of the so-called eastern integration expansion. In particular, changes in the development trends of two groups of industries - the group of industries reflecting the development of human well-being (education including research and development, health care, social care, culture, entertainment, recreation, public administration), which corresponds to the concept of the quaternary sector according to Mallick and Kraftová (2015) - and on the other side the manufacturing industry, which still underlines the dynamics of globalization changes and technical, technological and economic changes implemented by both the market and the public sector (Kraftová, 2011). In addition, new institutional approaches are applied to find a solution to the problem of (non) 
competitiveness of countries and regions, the development of vertical links between firms global commodity chains (GCC), global value chains (GVC), and global productivity networks (GPN) is also being considered (Blažek, 2012). Besides examining the consequences of globalization trends on the agenda, however, there are debates about the demonstrations of deglobalization (Postelnicu, Dinu, \& Dabija, 2015), such a trend would most likely also lead to changes in the positions of countries and regions in the world economy.

Finally, attention is also paid to the shifts in market structures, which, according to Kraft (2016), are influenced by the natural (economically rational) behaviour of the parties to the supply side, and the changes are also stimulated by the applied economic policy instruments, especially in the EU member states. Changes in the economic structure take place continuously, with greater or lesser intensity, with a variety of factors affecting them. Maskell et al. (1998) considers one of the important factors internationalization, which brings about a process of ubiquitalization (previously localized factors become more or less available in different parts of the world), while at the same time they point out that the specialization patterns have been stabilized, both at national and regional level.

However, it seems that not all actors are satisfied with this situation and the issue of socalled smart specialization, the identification of domains of intelligent specialization is included in EU strategic documents (EC, 2010) but also in individual member states, e.g. the Czech Republic (Ministry of Education, Youth and Sport of the CR, 2014), or even regions and settlements (Maštálka \& Vávra, 2016). Discussion on this topic in the Czech Republic concerns the GDP structure, resp. the structure of gross added value. Dlouhý (2016), the leading representative of the Czech Chamber of Commerce, opposes the view that manufacturing industry must gradually retreat to more modern sectors, especially services, and reports to the digitization of industry and the reindustrialization of the economy. This view is also held by Korbel (2016), who also highlights the fact that the export of Czech products is often realized through German companies. In line with Rogoff (2012), both named agree that changes in the structure of GDP must be backed up by a change in the approach to support for science, research and education, which is a prerequisite for flexibility in absorbing job changes induced by technological advances.

Increased attention is paid to the analysis of exports in terms of searching for a comparative advantage (Fojtíková, 2016; Saboniene, 2009). Nevertheless, according to published analysis, Europe's share of world GDP is declining, as is the share of European exports, and the world's top ten companies are dominated by China and the USA (Red, 2013). Not only the status of Europe is changing. Although the forecast of the International Monetary Fund (IMF) did not meet, that the GDP of China would reach the GDP of the USA in 2014 (Sachs, 2014), the USA forecast of $\$ 17.4$ trillion came out completely, but China did not reach according to the UNSTAT data (UNSTAT, 2016) 17.6 trillion USD, but "only" 10.9 trillion USD at current prices. However, it is more than double compared to 2009. Humankind will still have to wait for the anticipated advance of the performance of China's economy as opposed to the USA as it did until 1889 (Sachs, 2014), but China's dynamic onset at the end of the 20th century leaves no doubt about how powerful a world player is in the game.

Recently, in the application industry sector, but also in the sphere of decision-making and academic use of the synonym for the Fourth Industrial Revolution, "Industry 4.0", has not only its technical dimension (robotics, internet of things, intelligent factories) but needs to be seen in a wide socioeconomic context (Vacek, 2016; Jirsák et al., 2016). Concept Industry 4.0 creates, according to Kotynková (2016), a "digital discourse" in the Czech Republic, (it can be said that this is not the case only for the Czech Republic). Kotynková also points out that economic integration is a strong aspect of Europe. Economic actors advancing on their own short-term national interests should not be listened to. "This leads to fragmentation and small games that lack a great win." (Kotynková, 2016, p. 1020).

Nevertheless, for the outlined fact of the beginning of the Fourth Industrial Revolution, information and communication technologies become crucial in both the processing industry and the services (Půžová \& Marešová, 2014). Their impact on GDP growth and regional development is evidenced by several studies (Gatautis, 2008; Volejníková \& Lelek, 2012; Doucek, Maryška, \& Novotný, 2013). 


\section{Research Sample and Methodology Used}

The "big" world economies are selected on the basis of their absolute GDP in 2015 (UNSTAT, 2016), which represent the percentage of the share of world's GDP: the USA (25.1\%); China $(9.6 \%)$; Japan $(8.4 \%)$ and Germany $(5.5 \%)$; in the range of 3 to $5 \%$ of the world's GDP, there is also the United Kingdom and France.

The countries that make up the main comparative basis for the Czech economy are all under one percent share of the world's GDP: Poland $(0.75 \%)$, the Czech Republic $(0.26 \%)$, Hungary $(0.20 \%)$, Slovakia $(0.12 \%)$, Lithuania $(0.06 \%)$, Latvia $(0.03 \%)$ and Estonia $(0.03 \%)$.

The research focuses on the period from 1993 to 2015 . The reason for this selection is the attempt to capture a relatively long period, which is defined in the early 1990s, when the transformation takes place of the socio-economic relations in a number of European states causing the so-called third wave globalization (Besides, in 1993, former Czechoslovakia was divided into two republics - Czech and Slovak). The second landmark (year 2015) represents the last year with full relevant statistical data. With regard to selected research methods, the selected reference years are: 1993, 2000 and 2015. Years 1993 and 2015 are, for the reasons mentioned above, marginal years, year 2000 was chosen as the year that was in terms of economic development both in the world and in the analyzed countries relatively "calm". The V4 and Baltasam (Estonia, Lithuania, Latvia) countries were only been preparing for accession to the European Union; China's path of highly dynamic growth began only at the turn of 2005/2006.

The indicators used - GDP (for determining the world's big economies), gross value added (VA), import (IM), export (EX) - are extracted from United Nations statistics (UNSTAT and UNCTADSTAT). The International Standard Industrial Classification of All Economic Activities (ISIC) Rev. 3 is applied, where the relevant sector is Manufacturing (ISIC D) and Transport, Storage and Communication (ISIC I). To date, comparable data for ISIC Rev. 4 is not available, where there is already a separate class for Information and Communication (ISIC J). In the case of ISIC D gross added values for China for the years of 1993 and 2000, the unpublished values were replaced by an estimate using the geometric mean of the growth index of this indicator for the years 2004 to 2015, knowing that the linear trend shows a coefficient of determination of 0.98 . Verification of the correctness of the estimate was made by calculating the ISIC D gross added value to the ISIC group C to $\mathrm{E}$, which slightly oscillated around the average of $78.32 \%$ between 2004 and 2015. In this way, the estimated values differ from the values calculated by the first method to the order of a thousandth of a percent. Therefore, the estimated values can be considered acceptable. All default values for calculations are applied in the same units (USD, current prices). In the case of import and export data, attention is focused on the item "total ICT goods", which - according to the 2012 OECD Harmonized System (HS12) for the information society description - covers 93 sub-items. (OECD, 2011; UNCTAD, 2014)

The location quotient (LQ) is used to determine changes in localization rate of the sector concerned across the region or country within a larger unit and the regional concentration of industry (IRC) index is used to determine sector concentration rate within a region. In both cases these are composite ratios - see formula (1), resp. (2).

$$
\begin{gathered}
L Q_{I, R}=\frac{V A_{I, R}}{V A_{R}} \div \frac{V A_{I, T}}{V A_{T}} \\
I R C_{I}=\frac{V A_{I, R}}{V A_{I, T}} \div \frac{V A_{R}}{V A_{T}}
\end{gathered}
$$

where $V A$ = value added; index I = I-th industry; index $R=\mathrm{R}$-th region, here country; index $T=$ total value, here world.

It should be noted that each of them evaluates the problem from a different point of view, although their final result is of the same value. This is evident from the relationship (3).

$$
\frac{V A_{I, R}}{V A_{R}} \times \frac{V A_{T}}{V A_{I, T}}=\frac{V A_{I, R}}{V A_{I, T}} \times \frac{V A_{T}}{V A_{R}}
$$

The localization and concentration rate of the ISIC D and ISIC I sectors are analyzed in the first part of the survey for each country relative to the world, based on the relevant values of the gross value added indicator. For both indicators, the reference value is " 1 " with which the final results are measured.

The second part of the research concerns only ISIC I and uses the tailored model SHADE 
(Kraftová, Matěja, \& Zdražil, 2013) to determine the change in the position of the countries compared to the growth dynamics of this sector between 1993 and 2000, resp. 2000 and 2015 and its share of the country's total gross added value, both in 2000 and 2015. The SHADE (SHAre-DEvelopment) model has been modified, which in its basic form operates with two levels both for the share and the growth (high-low). For finer resolution, the model was treated as a three-step process. Matrices are divided into 9 sectors; on the horizontal axis, the share of the sector in value added is recorded in 2000 , respectively 2015 with levels to $7.5 \%$ (low), from 7.5 to $15 \%$ (medium) and from 15 to $22.5 \%$ (high); on the vertical axis the growth rate of the industry in the period 1993-2000, respectively 2000-2015: 0 to $2 \%$ (low), from 2 to $4 \%$ (medium) and from 4 to $6 \%$ (high growth).

The third part of research focuses on the competitiveness of countries in the area of ICT goods. For this purpose, the Balassa index (BI) is used - see formula (4), which is de facto the type of localization quotient in terms of export monitored export item and region to the superior unit and the revealed comparative advantage (RCA) index - see formula (5), which measures net exports of rated commodity item with total foreign trade turnover. The items with the largest RCA then represent an advantage for a given country in the sense of Ricard's theory of comparative advantages. Given the absence of data for 1993, this part of the analysis only covers the years 2000 and 2015.

$$
\begin{aligned}
& B I_{J, R}=\frac{E X_{J, R}}{E X_{R}} \div \frac{E X_{J, T}}{E X_{T}} \\
& R C A_{J}=\frac{E X_{J, R}-I M_{J, R}}{E X_{R}+I M_{R}}
\end{aligned}
$$

where $E X=$ export, $I M=$ import, Index $J=J$-th commodity item, Index $R$ a $T$ - see above.

\section{Results}

The following three sections present the results of the analysis of both groups of selected countries in terms of localization and regional concentration of ISIC D and ISIC I, in terms of the development and share of the ISIC I sector in value added and in terms of localization of ICT goods exports and the identification of comparative advantages in these commodities.

\subsection{Context of the Localization and Concentration of ISIC D and ISIC I in Selected Countries}

It could be simply stated that the localization quotient, resp. the index of the regional concentration of ISIC D - compared to the world economy as a whole - for three major economies (the USA, the United Kingdom, France) is smaller than the world share in all reference years, while the remaining three major economies (China, Japan, Germany) exceeds the world value. In transition economies, ISIC $D$ plays a bigger role than the world as a whole, with exceptions: 1993 Slovakia, 2000 Latvia, 2015 Latvia and Estonia. These facts are influenced by the overall sectoral structure of the national economy, where it is significant what segment of the imaginary cake is occupied by the service sector, including mainly finance, public administration, education, health, social services (ISIC J to P), and how the remainder of the cake is distributed among other industries of primary, secondary and tertiary sectors. From the point of view of the above-mentioned service sectors (ISIC $\mathrm{J}$ to $\mathrm{P}$ ), two extremes in the two subgroups of countries are apparent at the beginning of the period under review: their maximum share in the gross value added of their economy is reached by the USA (57\%), among the transforming economies it is Hungary (47\%); China (only $23 \%$ ), resp. Lithuania (only $26 \%$ ). China, on the other hand, dominates large economies with its share of the manufacturing industry (ISIC D), which even exceeds the share of the service sectors by 2 percentage points. Other major economies with a share of the manufacturing industry (ISIC D) around one fifth of the total gross value added are Germany $(22 \%)$ and Japan (19\%). From the transforming countries, the share of the manufacturing industry (ISIC D) is comparable to that of Japan only by Lithuania $(19 \%)$, which records the above minimum in service sectors defined as ISIC $\mathrm{J}$ to $\mathrm{P}$.

The ISIC I sector, including ICT, is more diverse - in 1993, China and Germany are under the global concentration; China, Germany and Poland in 2000; China alone in 2015 -, but the actual resulting value of the localization quotient or index of the regional concentration of the industry gives little information. Therefore, further comment on the results of the research is based on the calculations presented in Appendix 1 and Appendix 2 and focuses on 
Tab. 1: Positions of groups of countries in the years under review for ISIC D

\begin{tabular}{c|c|c|c}
$\begin{array}{c}\text { Position } \\
\text { pattern }\end{array}$ & $\begin{array}{c}\text { Relation of the share } \\
\text { of the gross added } \\
\text { value of the industry } \\
\text { to the world's gross } \\
\text { added value against } \\
\text { the analogue country } \\
\text { share }\end{array}$ & $\begin{array}{c}\text { The relation of the country's } \\
\text { gross value added of industry } \\
\text { share of the country's gross va- } \\
\text { lue added against the country's } \\
\text { gross value added of industry } \\
\text { to total gross value added of the } \\
\text { industry }\end{array}$ & $\begin{array}{c}\text { Relation of the country's } \\
\text { gross value added of } \\
\text { industry share of the total } \\
\text { gross value added of the } \\
\text { industry against the coun- } \\
\text { try's share of total gross } \\
\text { added value }\end{array}$ \\
\hline $\mathrm{I}$ & $\mathrm{VA}_{\mathrm{I}} \mathrm{VA}_{\mathrm{T}}: \mathrm{VA}_{\mathrm{IR}} / \mathrm{VA}_{\mathrm{R}}$ & $\mathrm{VA}_{\mathrm{IR}} / \mathrm{VA}_{\mathrm{R}}: \mathrm{VA}_{\mathrm{IR}} / \mathrm{VA}_{\mathrm{I}}$ & $\mathrm{VA}_{\mathrm{IR}} / \mathrm{VA}_{\mathrm{I}}: \mathrm{VA}_{\mathrm{R}} / \mathrm{VA}_{\mathrm{T}}$ \\
\hline $\mathrm{II}$ & $>$ & $<$ & $<$ \\
\hline $\mathrm{III}$ & $>$ & $>$ & $<$ \\
\hline
\end{tabular}

Source: own processing using UNSTAT data

Note: For explanation of symbols see formula (1) and (2)

identical or different relational moments of the structure of national economies in terms of ISIC $\mathrm{D}$ and ISIC I.

\section{Position patterns in terms of ISIC D}

In the assessment of the position of the country from the point of view of the manufacturing industry (ISIC D), three groups with different relations were formed in each of the analyzed years, as shown in the Tab. 1, from which it is possible to derive its "position pattern" within the world.

The position pattern I shows only the USA in all three years. It is an economy that does not reach the ISIC D share of gross value added as the whole world, corresponding to even the smaller ISIC D USA share of the total gross added value of the industry, but the total gross value added by the USA is more than the world's share of the gross added value of ISIC D. The country's performance is the world's largest, but it is not dominated by the manufacturing industry.

The position pattern II includes all of the United Kingdom and France in all three years, which in 1993 is joined by Slovakia, which is replaced by Latvia in 2000 and Estonia is also joined in 2015. Their position is characterized by a lower proportion of ISIC D added across the country than ISIC D to total gross added value, but the share of ISIC D in the national economy is higher than the share of this industry in the country's gross added value. These countries contribute to total gross added value by more performance in other industries, similarly as the USA.
The position pattern III belongs to other countries not listed above, i.e. China, Japan, Germany, Poland, the Czech Republic, Hungary and Lithuania. Their share of ISIC D in the gross added value of the national economy is higher than that of the whole world and exceeds the country's share in the total gross added value of ISIC D. In contrast, their share in total gross added value does not reach the amount they contribute to gross value added ISIC D. For these countries, the manufacturing industry is a very important sector of the economy.

\section{Position patterns in terms of ISIC I}

In the ISIC I industry, the situation is more complex, as position patterns are less stable, moreover it is new, specific - see Tab. 2.

The position pattern I with an analogous explanation as for ISIC D is represented, and only in 2015 , by China. For China, the ISIC I is not the most important industry, but given the share of its gross added value in global production, it cannot be said that it would be a minor player in this respect.

The position pattern II - again in analogy as with ISIC D - is held by China and Germany in 1993; Poland joined in 2000. In these periods in those countries, therefore, the importance of ISIC I within the national economy is greater than that of a global one, with a significant share of the country in global economic performance. In 2015, this type of position pattern in ISIC I is not filled by any of the countries surveyed.

The positional pattern III - in analogy as in the case of ISIC D - it characterizes the 


\begin{tabular}{c|c|c|c}
$\begin{array}{c}\text { Position } \\
\text { pattern }\end{array}$ & $\begin{array}{c}\text { Relation of the share } \\
\text { of the world's gross } \\
\text { added value of the } \\
\text { industry to the total } \\
\text { gross added value } \\
\text { against the analogue } \\
\text { country share }\end{array}$ & $\begin{array}{c}\text { Relation of the industry gross } \\
\text { value added share of the coun- } \\
\text { try's gross value added against } \\
\text { country's gross added value of } \\
\text { the industry to the total gross } \\
\text { added value of the industry }\end{array}$ & $\begin{array}{c}\text { Relation of the count- } \\
\text { ry's gross added value } \\
\text { of the industry to the } \\
\text { total gross added value } \\
\text { of the industry against } \\
\text { the country's share of } \\
\text { total gross added value }\end{array}$ \\
\cline { 2 - 4 } & $\mathrm{VA}_{\mathrm{I}} / \mathrm{VA}_{\mathrm{T}}: \mathrm{VA}_{\mathrm{IR}} / \mathrm{VA}_{\mathrm{R}}$ & $\mathrm{VA}_{\mathrm{IR}} / \mathrm{VA}_{\mathrm{R}}: \mathrm{VA}_{\mathrm{IR}} / \mathrm{VA}_{\mathrm{I}}$ & $\mathrm{VA}_{\mathbb{R}} / \mathrm{VA}_{\mathrm{I}}: \mathrm{VA}_{\mathrm{R}} / \mathrm{VA}_{\mathrm{T}}$ \\
\hline $\mathrm{I}$ & $>$ & $<$ & $<$ \\
\hline $\mathrm{II}$ & $>$ & $>$ & $<$ \\
\hline $\mathrm{III}$ & $<$ & $>$ & $>$ \\
\hline $\mathrm{IV}$ & $<$ & $<$ & $<$ \\
\hline
\end{tabular}

Source: own processing using UNSTAT data

ISIC I position pattern for "other" countries, i.e., except for countries with position patterns I, II and IV (the United Kingdom, France, the Czech Republic, Hungary, and the Baltasam countries). Simplified: For these countries, ISIC I is more significant than their share in the global ISIC I performance, but given the overall lower share of their economy in the world's gross added value, they do not play a decisive role in this industry.

The position pattern IV expands their spectrum in ISIC I compared to ISIC D. In 1993 and 2000 it is presented by Japan and the USA for ISIC I, and in 2015 Japan switches to position pattern III, i.e. among so-called "other" countries, and the position pattern IV is only filled by the USA. This is associated with a situation where the share of the ISIC I industry in the total world gross value added does not reach its share in the national economy, with the country's share in the industry being larger in terms of the total gross value added of the ISIC I industry and, at the same time, exceeds the share of the total national economy in the gross added value of the world. In other words, at the beginning of this century, besides the USA, Japan also held the position of a world leader in the ISIC I industry, and in 2015 it is only the USA that enjoys this privileged position.

From a comprehensive view of the importance of the industry in the national economies, one more consideration is worthwhile. This is the value of the localization quotient. When applying the idea of a dominant basic industry, if $L Q>1.5$ (Kraftová \& Prášilová, 2013) ISIC D can be identified as the dominant basic industry for China in all three years under review (with 1993 values: 1.66; 2000: 1.84; 2015: 1.63) and for the Czech Republic with the exception of 1993 (with values for 2000: 1.51; 2015: 1.63). It should be noted that in 2015 it is also Hungary who is attacking the position of the dominant basic industry of ISIC D where the localization quotient reaches 1.49. In addition, the ISIC I industry (incl. ICT) appears to be dominant basic in all three years in Latvia (with values for 1993: 3.06; 2000: 1.93; 2015: 1.67) and Estonia (with values for 1993: 1.85; 2000: 1.73; 2015: 1.63). Over time, the localization quotient of ISIC I is growing in Lithuania, where this industry is manifested as dominant in 2015 with $L Q=1.78$.

\subsection{ISIC I Position in Terms of Growth and Share of Gross Value Added}

Using the SHADE model, which compares the position of countries by ISIC I share of the country's gross value added in 2000 , resp. in 2015 and the dynamics of its growth between 1993 and 2000, resp. 2000 and 2015, Figs. 1a and $1 \mathrm{~b}$ show at first glance the changes that have occurred over time.

China maintains its exceptional low ISIC I share in country's gross added value (in both cases in the first third of the projected values, but thanks to its growth it reaches in the second period as the only one the highest third of the growth index.) The remaining 5 major economies 
Fig. 1a: ISIC I in Model SHADE 1993-2000

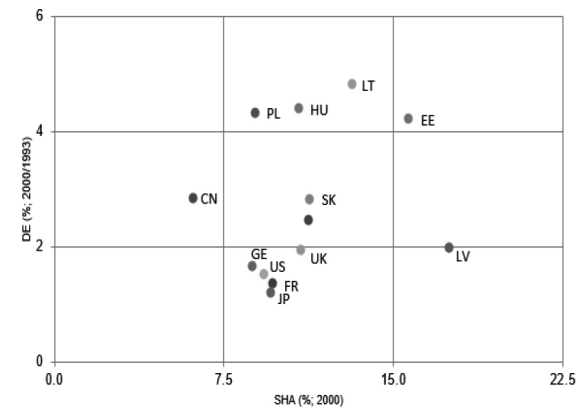

Fig. 1b: ISIC I in Model SHADE 2000-2015

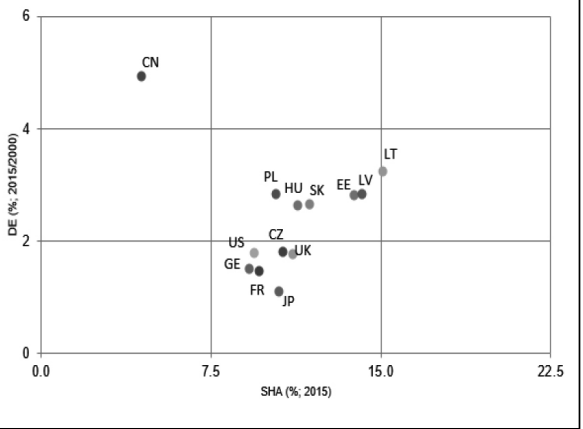

Source: own processing using UNSTAT data

Note: US = United States of America; CN = China; JP = Japan; GE = Germany; UK = United Kingdom; FR = France; $\mathrm{PL}=$ Poland; CZ = Czech Republic; HU = Hungary; SK = Slovakia; LT = Lithuania; LV = Latvia; EE = Estonia

of the world remain in both periods in a field characterized by a moderate share of country's gross value added and low growth. What is also interesting is the change in the positions of the V4 countries and the three Baltasam countries. In the first period, they show a relatively high spread within the medium and high share and growth, in the second period the ISIC I share in the total gross added value is reduced to the middle level, which brings them to the "big five", but still maintaining - with the exception of the Czech Republic - a medium level of growth.

\subsection{Localization of the Export of ICT Goods and Determination of the Comparative Advantages of the ICT Goods Countries}

Before evaluating the Balassa index (calculated similarly as the RCA index from the data listed in Appendix 3) for ICT goods in 2000 and 2015, it should be noted that while total exports between the years 2015 and 2000 grew worldwide by 2.64 index - in the analyzed group of countries with a variation range of 6.78 between the highest value achieved by China (8.16) and Japan's lowest value (1.38), the export growth index of ICT goods shows much higher variability (variation range 82.38 ), although the global growth index was on the level of 1.95, i.e. significantly lower than the overall export growth rate. Of course, it is important to point out that high growth rates from a small base are easier to achieve (manifestation of the mentioned ß-convergence), which is undoubtedly the case of Latvia (the export growth index of ICT goods 82.75) and Slovakia (the same index at 31.96). Interestingly, there is a relationship between growth in total exports and the export growth of ICT goods, which has been nearly four times higher in the Czech Republic, 2.5 times in Poland, and more than 1.5 times in China. By contrast, the original leaders - the USA, Japan, but also the United Kingdom and France - have seen a decline in ICT goods exports. The large economies of the world - besides China - the export growth of ICT goods is also growing in Germany, but even this is not reaching global growth in export of this commodity.

The Balassa index values captured in Fig. 2 for the two reference years indicate the ratio to the world position of ICT exports being found by the rated countries. Estonia, Japan and the USA are significantly losing for the years under review. Winners can then be designated: China, Slovakia and the Czech Republic.

Although global ICT trade turnover fell between 2000 and 2015 , by 3 percentage points (from 0.13 to $0.10 \%$ ), and most of the countries surveyed have also declined to varying degrees, it is pleasing that, in addition to China (an increase of 6 percentage points 


\section{Fig. 2: The Balassa Index for ICT goods of selected countries in 2000 and 2015}

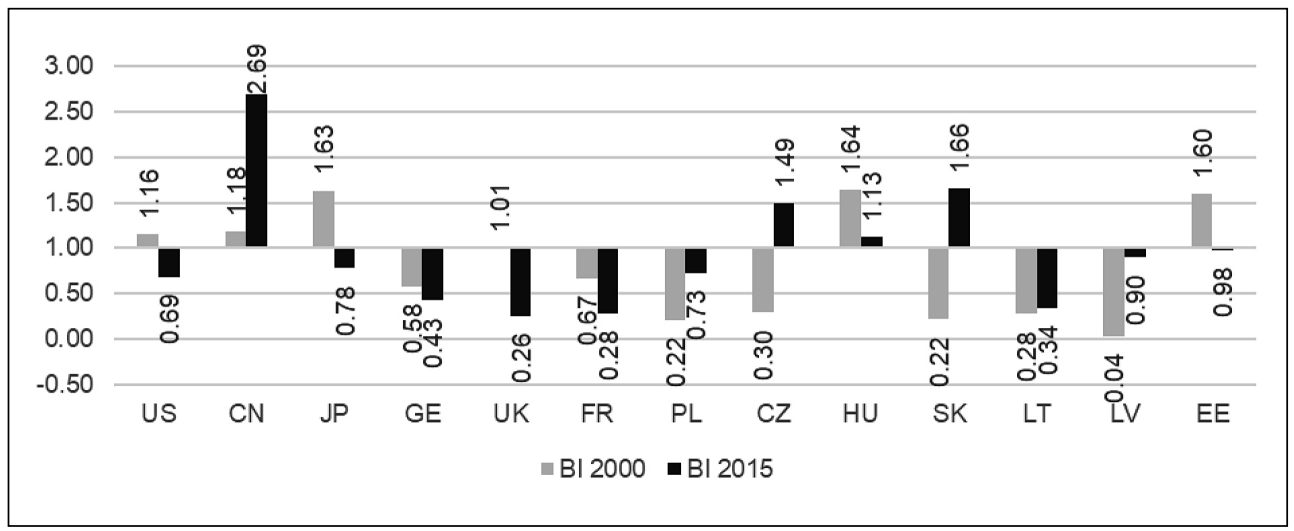

Source: own processing using UNCTADSTAT data

Note: Country abbreviations as with Fig. 1

- from 0.16 to $0.22 \%$ ), there is an increase in the share of this segment in Slovakia - by 11 percentage points (from 0.04 to $0.15 \%$ ), in the Czech Republic - by 9 percentage points (from 0.06 to $0.15 \%$ ), in Latvia - by 6 percentage points (from 0.03 to $0.09 \%$ ) and in Poland by 2 percentage points (from 0.06 to $0.08 \%$ ). However, this growing share of ICT goods in the country's foreign turnover does not yet mean that the given segment represents a comparative advantage for a given country. In this way, it is possible to describe the fact that a country reaches a positive RCA value, i.e. the export exceeds the import of the given commodity group. The results of the RCA analysis are presented in Tab. 3.

A comparative advantage was the ICT goods segment for three of the countries surveyed in 2000 (Japan, Hungary, Estonia), of which only Hungary retained this advantage also in 2015. The remaining two countries were replaced by China and Slovakia. This is also associated with a relatively significant increase in the turnover of ICT goods in total foreign trade. In other countries that are also showing this trend (the Czech Republic, Poland, Latvia) the import of these commodities plays a bigger role which may also mean a positive saturation of the needs in the direction of digital economy development.

\section{Tab. 3: RCA Index values of selected countries in 2000 and 2015}

\begin{tabular}{|c|c|c|c|c|c|}
\hline Country & 2000 & 2015 & Country & 2000 & 2015 \\
\hline US & -0.0246 & -0.0354 & $P L$ & -0.0311 & -0.0061 \\
\hline $\mathrm{CN}$ & -0.0024 & 0.0476 & $\mathrm{CZ}$ & -0.0243 & -0.0024 \\
\hline JP & 0.0479 & -0.0180 & $\mathrm{HU}$ & 0.0105 & 0.0011 \\
\hline $\mathrm{DE}$ & -0.0097 & -0.0096 & SK & -0.0129 & 0.0097 \\
\hline UK & -0.0220 & -0.0204 & LT & -0.0076 & -0.0069 \\
\hline FR & -0.0055 & -0.0117 & LV & -0.0272 & -0.0027 \\
\hline & & & EE & 0.0313 & -0.0030 \\
\hline
\end{tabular}

Source: own processing using UNCTADSTAT data

Note: Country abbreviations as in Fig. 1 


\section{Discussion}

In the evaluation of the analysis results, it should be emphasized that the localization quotient (LQ), the index of the regional concentration of the industry (IRC) as well as the SHADE model are based on the gross added value (not e.g. employment), i.e. the performance view, the rate of wealth creation. The second unavoidable fact in evaluating using relational indicators is the quantum of the share of the country or its industry at the relevant global value. Finally, it is necessary to take into account the differences in the sectoral structure of highly developed economies (the prevalence of the tertiary sector, minimum of the primary sector), compared to the less developed economies, where services do not play such a role, and the unachieved wealth creation is divided between the secondary (in particular) and the primary sector.

The defined position pattern of the countries from the point of view of the manufacturing industry (ISIC D) and the ICT (ISIC I) show that there are differences between countries in how they achieve their position. In fact, it is the countries with a different position pattern that reach the exceptional position in the world over the rest of the world, such as the USA in ISIC D, Japan, USA and Germany in ISIC I.

It cannot be said that the differences in localization, resp. the concentration of the industry surveyed were determined by the size of the economy or its membership of traditional market economies. From the point of view of the manufacturing industry's concentration, it is China which plays the first violin on the verge of the Fourth Industrial Revolution (although its $L Q=I R C$ declined somewhat between 2000 and 2015), the cause of this phenomenon may be compounded by the overall development of the Chinese economy, which is starting to develop the tertiary sector, not only the part serving the production sphere, but also the part connected with the growth of individual well-being, or the whole society). Similarly, the concentration of ISIC D in the Czech Republic is significantly increasing (in 2015 there is almost the same level of regional concentration as China), and also Hungary and Germany. Of course, it is necessary to see that the concentration of the manufacturing industry in China and Germany is far more important for worldwide performance, but the reality of the Czech and Hungarian economies is very significant, especially if their processing industry is timely and properly transformed into its form corresponding to the Fourth Industrial Revolution.

In contrast, the United Kingdom, France, and the USA (three large, traditional market economies) are significantly losing in terms of ISIC D over the reference period, which can be similarly explained by their further increase in labor productivity and capital and changes in the sectoral structure for the benefit of the tertiary sector. It is also the case of Latvia, which entered into a relatively even sectoral structure in the early 1990s, a characteristic of a less developed country, therefore, this loss is quite fundamental for them. There is a hidden danger of being unable to engage adequately in the implementation of the Fourth Industrial Revolution, precisely because of the low concentration of manufacturing industry that would absorb new digital features. Its chances could be found in the intensive development of the ICT, which would saturate other countries with the necessary commodities.

If abstracted from inaccuracies which are based in the ISIC I Rev. 3 set up, where ICT is only part of the ISIC I, it can be said that unlike the manufacturing industry - China, in the period under review is still losing, resp. the ISIC I concentration is still below the global level and, moreover, decreases. On the other hand, Lithuania, Slovakia, the United Kingdom, Hungary, Japan - the "small" and "big" economies, the traditional market and the transformed ones, have seen growth of ISIC I over the period under review. Special development is recorded by Germany, which in terms of ISIC I reached in 2015 from the level below the reference value "1" above it. Interestingly, the Czech Republic, which has also increased its concentration of ISIC I, but compared to all previous countries with lower dynamics between 2000 and 2015. Three of the monitored countries - the USA, France and Poland - seem to have recovered after 2000. The previous decrease in ISIC I concentration is replaced by its growth so that it is above the reference value of " 1 ".

The SHADE model, evaluating the national economy in terms of its ICIT I, confirms the exceptional development and position of ISIC I in the Chinese economy (although, as noted above, its global perception is somewhat different). This model confirms the similarity of the traditional market economy vs. groups of 
transformed economies of the former Soviet bloc. An "exceptionally valid rule" is the Czech Republic, which through its position in the period 2000-2015 joined the traditional market economies. This can be justified by a higher degree of maturity of the Czech economy in the given direction, but also by a decrease in the dynamics of the development in the last evaluated period, as mentioned above.

Exportability in ICT goods, measured by the Balassa index, positively evaluates those economies that have managed to increase their positive Balassa index (China, Hungary) over time, or rather to get from its negative values to positive ones (the Czech Republic, Slovakia). If a RCA indicator is used to assess the comparative advantage of countries in a given commodity group, China, Hungary and Slovakia have this comparative advantage at the threshold of the Fourth Industrial Revolution. Japan and Estonia, which boasted the positive RCA in 2000 , do not have this advantage in 2015.

\section{Conclusions}

The beginning of the Fourth Industrial Revolution is an unrepeatable moment of human history, just as it was with the First, Second and Third Industrial Revolutions. The one who knows and is able to accept, use and multiply the supporting trends is the one who gains. It has often been mentioned: "It's not the big that eats the small, it's the fast that eats the slow".

It is undisputed that the manifestations and consequences of the Fourth Industrial Revolution will continue to be examined not only in the context of cyber-physical production systems, but also that their multidisciplinary contexts will be evaluated. It is undoubtedly important that it is associated with the premise of highly dynamic socio-economic development, although each chance is balanced by danger or risk. Socio-economic development is not necessarily versatile and smooth, it is necessary to perceive the pitfalls of the whole process and react in time to possible negative signals.

To clarify the examination of the manifestations and consequences of the Fourth Industrial Revolution for individual economies of the world or their clusters, it is satisfactory to note that even the statistical data base has gone through changes that the International Standard Industrial Classification of All
Economic Activities (ISIC) has been elaborated in its Rev. 4, in which the code $\mathrm{J}$ is just devoted to "Information and Communication".

The international competitive environment is changing as well as the positions of individual national economies in it. "Small" economies do not reach in the absolute level the performance of "big" economies, but they can, in a relative degree - especially thanks to the appropriate sectoral specialization, use their comparative advantages - gain substantially. Due to the dynamics of the development of modern technologies, social and economic sciences must also be prepared to analyse and evaluate socio-economic processes, to find answers to new questions and to address possible negative consequences of the Fourth Industrial Revolution.

The paper was supported by the University of Pardubice, Faculty of Economics and Administration, Project SGS_2017_021 „Threats and Opportunities for Implementation of the Concept of Smart Cities and Smart Region in the Context of Regional Development".

\section{References}

Blažek, J. (2012). Regionální inovační systémy a globální produkční sítě: dvojí optika na zdroje konkurenceschopnosti v současném světě? Geografie, 117(2), 209-233.

Dlouhý, V. (2016). Neničme talenty, průmysl to ocení. Svět 2017. Praha: Economia.

Doucek, P., Maryška, M., \& Novotný, O. (2013). Analýza souladu obsahu ICT studijních oborů s požadavky praxe v České republice. E\&M Ekonomie a Management, 16(3), 148-161.

European Commission. (2010). Evropa 2020. Strategie pro inteligentní a udržitelný růst podporující začlenění. Brusel: COM.

Fisher, A. G. B. (1939). Production, primary, secondary and tertiary. Economic Record, 15(1), 24-38. https://dx.doi. org/10.1111/j.1475-4932.1939.tb01015.x.

Fojtíková, L. (2016). Trends in the revealed comparative advantages of the EU member states. Economic Annals-XXI, 161(9-10), 7-11. https://dx.doi.org/10.21003/ea.V161-02.

Garvy, G. (1943). Kondratieff's Theory of Long Cycles. The Review of Economics and Statistics, 25(4), 203-220. https://dx.doi. org/10.2307/1927337.

Gatautis, R. (2008). The Impact of ICT on Public and Private Sectors in Lithuania. 
Inzinerine Ekonomika-Engineering Economics, 59(4), 18-28.

Grinin, L. E., Grinin, A. L., \& Korotayev, A. (2017). Forthcoming Kondratieff wave, Cybernetic Revolution, and global ageing. Technological Forecasting \& Social Change, 115, 52-68. https://dx.doi.org/10.1016/j. techfore.2016.09.017.

Jirsák, P., Martinéz, F., Lorenc, M., \& Jančík, J. (2016). Industry 4.0 in the Czech Republic - State of the Art. In Proceedings of the $10^{\text {th }}$ International Days of Statistics and Economics (pp. 766-769).

Kamensky, E. (2017). Society. Personality. Technologies: Social Paradoxes of Industry 4.0. Economic Annals, XXI, 164(3-4), 9-13. https://dx.doi.org/10.21003/ea.V164-02.

Korbel, P. (2016). Reindustrializace je cestou k bezpečí. Svět 2017. Praha: Economia.

Kotynková, M. (2016). Industry 4.0: Europe's (Re)Industrialization Needs a Global Level. In Proceedings of the $16^{\text {th }}$ international scientific conference Globalization and its Socio-economic Consequences (pp. 1014-1021).

Kraft, J. (2016). Analysis of Changes in Selected Market Structures in Relation to Economic Success. Inzinerine EkonomikaEngineering Economics, 27(1), 32-28. https://dx.doi.org/10.5755/j01.ee.27.1.9734.

Kraftová, I. (2011). Odvětvové změny a rozvoj regionů. ERSA, Zimný seminár regionálnej vedy (pp. 1-14).

Kraftová, I., Matěja, Z., \& Zdražil, P. (2013). Innovation Industry Drivers. In Proceedings of the $11^{\text {th }}$ International Conference Liberec Economic Forum (pp. 334-342). Liberec: Technická univerzita $\vee$ Liberci.

Kraftová, I., \& Prášilová, P. (2013). Prosperující podnik v regionálním kontextu. Praha: Wolters Kluwer ČR.

Li, G., Hou, Y., \& Wu, A. (2017). Fourth Industrial Revolution: Technological Drivers, Impacts and Coping Methods. Chinese Geographical Science, 27(4), 626-637. https:// dx.doi.org/10.1007/s11769-017-0890-x.

MacDougall, W. (2014). Industrie 4.0. Smart Manufactruing for the Futurre. Berlin: GTAI.

Makridakis, S. (2017). The forthcoming Artificial Intelligence (AI) revolution: Its impacts on society and firms. Futures, 90, 40-60. https://doi.org/10.1016/j.futures.2017.03.006.

Mallick, J., \& Kraftová, I. (2015). The Development of Quaternary Activities in Japanese Economy. Asian Economic Review, 57(2), 1-14.
Marais, G. (1981). Structural Changes in Manufacturing Industry 1916 to 1975 . South African Journal of Economics, 49(1), 16-27. https://dx.doi.org/10.1111/j.1813-6982.1981.tb00686.x.

Maskell, P., Eskelinen, H., Hannibalson, I., Malmberg, A., \& Vatne, E. (1998). Competitiveness, Localised Learning and Regional Development. (Specialisation and prosperity in small open economies). London and New York: Routledge.

Maštálka, M., \& Vávra, M. (2016). Koncept smart cities v prostředí České republiky. In V. Klímová \& V. Žítek (Eds.), $19^{\text {th }}$ International Colloquium on reginal Sciences (pp. 747-752). https://dx.doi.org/10.5817/CZ.MUNI.P2108273-2016-95.

Ministry of Education, Youth and Sport of the CR. (2014). Národní výzkumná a inovační strategie pro inteligentni specializaci České republiky (Národní RIS3 strategie). Retrieved July 29, 2017, from http://www.msmt.cz/ uploads/OP_VVV/Narodni_RIS3_strategie_ schvalena_vladou_8._12._2014.pdf.

OECD. (2011). Guide on Measuring the Information Society 2011. Retrieved July 27, 2017, from http://www.oecd.org/sti/ieconomy/oecdguideto measuringtheinformationsociety2011.htm.

Paci, R. (1997). More similar and less equal: Economic growth in the European regions. Review of World Economics, 133(4), 609-634. https://dx.doi.org/10.1007/BF02707405.

Postelnicu, C., Dinu, V., \& Dabija, D. C. (2015). Economic Deglobalization - from Hypothesis to Reality. E\&M Ekonomie a Management, 18(2), 4-14. https://dx.doi. org/10.15240/tul/001/2015-2-001.

Půžová, K., \& Marešová, P. (2014). Czech Republic's Competitiveness in ICT Market. Procedia - Social and Behavioral Sciences, 109, 880-885. https://dx.doi.org/10.1016/j. sbspro.2013.12.558.

PwC. (2017). Lidé a digitalizace byznysu. Průzkum názorů generálních ředitelů. Praha: Economia.

Red. (2013). Evropa na sestupu. Miríí do „druhé ligy“. Ekonom, 57(40), 47-51.

Rogoff, K. (2012). Poučení ze hry králů. Ekonom, 56(41), 38.

Rostow, W. W. (1985). Is There Need for Economic Leadership - Japanese or United States. American Economic Review, 75(2), 285-291.

Saboniene, A. (2009). Lithuanian Export Competitiveness: Comparison with other Baltic 
States. Inzinerine Ekonomika-Engineering Economics, 60(2), 49-57.

Saboniene, A. (2010). The Evaluation of the Potential of Lithuanian Manufacturing Industry Structure on the Basis of $\mathrm{Cl}$ Index. Inzinerine Ekonomika-Engineering Economics, 61(4), 399-407.

Sachs, J. D. (2014). Nová globální vedoucí role Číny. Ekonom, 58(49), 36.

The National Convention on the EU. (2016). Společnost 4.0. Praha: Hospodářská komora ČR.

UNCTAD. (2014). Updating the Partnership Definition of ICT Goods from HS 2007 to HS 2012. Retrieved July 27, 2017, from http:// unctad.org/en/PublicationsLibrary/tn_unctad_ ict4d02 en.pdf.

UNSTAT. (2016). GDP/breakdown at constant 2005 prices in US Dollars (all countries and regions). Retrieved March 22, 2016, from https://unstats.un.org/unsd/snaama/dnllist.asp.

Vacek, J. (2016). Socio-Economic Aspects of Industry 4.0. In Proceedings $4^{\text {th }}$ International Conference on Innovation Management, Entrepreneurship and Corporate Sustainability (pp. 731-741).

Volejníková, J., \& Lelek, T. (2012). Hospodářský růst $v$ éře nové ekonomiky. Scientific Papers of the University of Pardubice, Series $D, X X I(39 / 1), 98-106$.
Zdražil, P., \& Applová, P. (2016). Growth Disparities among Regions of the Visegrad Group Countries: An Evidence of Their Extent and Nature. E\&M Ekonomie a Management, 19(2), 37-53. https://dx.doi.org/10.15240/ tul/001/2016-2-003.

Assoc. Prof. Ivana Kraftová University of Pardubice

Faculty of Economics and Administration Institute of Regional and Security Sciences Czech Republic Ivana.Kraftova@upce.cz

Ing. Iveta Doudová University of Pardubice Faculty of Economics and Administration Institute of Regional and Security Sciences Czech Republic st41306@student.upce.cz

Bc. Radim Miláček University of Pardubice Faculty of Economics and Administration Institute of Regional and Security Sciences

Czech Republic st37794@student.upce.cz 


\section{Ekonomie}

\begin{tabular}{|c|c|c|c|c|c|c|c|c|c|c|c|c|}
\hline \multicolumn{2}{|c|}{ Appendix 1: } & \multicolumn{11}{|c|}{ ISIC D } \\
\hline year & 1993 & 1993 & 1993 & 1993 & 2000 & 2000 & 2000 & 2000 & 2015 & 2015 & 2015 & 2015 \\
\hline country & VAir/VAr & VAir/VAi & VAr/NAt & $L Q=I R C$ & VAir/VAr & VAir/VAi & VAr/NAt & $L Q=I R C$ & VAir/VAr & VAir/VAi & VAr/VAt & $L Q=I R C$ \\
\hline US & 0.1667 & 0.2402 & 0.2720 & 0.8831 & 0.1512 & 0.2839 & 0.3215 & 0.8829 & 0.1203 & 0.1859 & 0.2554 & 0.7280 \\
\hline $\mathrm{CN}$ & 0.3128 & 0.0408 & 0.0246 & 1.6568 & 0.3144 & 0.0695 & 0.0379 & 1.8357 & 0.2701 & 0.2547 & 0.1559 & 1.6340 \\
\hline$J P$ & 0.2309 & 0.2152 & 0.1760 & 1.2231 & 0.2117 & 0.1881 & 0.1522 & 1.2359 & 0.1862 & 0.0694 & 0.0616 & 1.1264 \\
\hline$D E$ & 0.2363 & 0.0934 & 0.0747 & 1.2512 & 0.2298 & 0.0738 & 0.0550 & 1.3415 & 0.2281 & 0.0592 & 0.0429 & 1.3800 \\
\hline UK & 0.1848 & 0.0351 & 0.0358 & 0.9790 & 0.1468 & 0.0393 & 0.0458 & 0.8570 & 0.0977 & 0.0213 & 0.0360 & 0.5913 \\
\hline FR & 0.1632 & 0.0413 & 0.0478 & 0.8646 & 0.1573 & 0.0353 & 0.0384 & 0.9186 & 0.1123 & 0.0208 & 0.0306 & 0.6795 \\
\hline PL & 0.2548 & 0.0046 & 0.0034 & 1.3494 & 0.1838 & 0.0051 & 0.0047 & 1.0730 & 0.1969 & 0.0071 & 0.0060 & 1.1916 \\
\hline $\mathrm{CZ}$ & 0.2341 & 0.0018 & 0.0014 & 1.2400 & 0.2591 & 0.0027 & 0.0018 & 1.5128 & 0.2697 & 0.0038 & 0.0024 & 1.6320 \\
\hline $\mathrm{HU}$ & 0.2037 & 0.0015 & 0.0014 & 1.0790 & 0.2243 & 0.0016 & 0.0013 & 1.3092 & 0.2459 & 0.0022 & 0.0014 & 1.4879 \\
\hline SK & 0.1864 & 0.0005 & 0.0005 & 0.9873 & 0.2391 & 0.0008 & 0.0006 & 1.3957 & 0.2245 & 0.0015 & 0.0011 & 1.3585 \\
\hline LT & 0.2775 & 0.0004 & 0.0003 & 1.4699 & 0.1886 & 0.0004 & 0.0003 & 1.1010 & 0.1934 & 0.0006 & 0.0005 & 1.1702 \\
\hline LV & 0.2197 & 0.0002 & 0.0002 & 1.1634 & 0.1535 & 0.0002 & 0.0002 & 0.8960 & 0.1263 & 0.0003 & 0.0003 & 0.7642 \\
\hline $\mathrm{EE}$ & 0.2163 & 0.0002 & 0.0001 & 1.1455 & 0.1730 & 0.0002 & 0.0002 & 1.0098 & 0.1584 & 0.0003 & 0.0003 & 0.9582 \\
\hline VAi/VAt & $\mathrm{x}$ & $\mathrm{x}$ & $\mathrm{x}$ & 0.1888 & $x$ & $x$ & $\mathrm{x}$ & 0.1713 & $x$ & $\mathrm{x}$ & $x$ & 0.1653 \\
\hline
\end{tabular}

Source: own processing 


\begin{tabular}{|c|c|c|c|c|c|c|c|c|c|c|c|c|}
\hline \multicolumn{2}{|c|}{ Appendix 2: } & \multicolumn{11}{|c|}{ ISIC I } \\
\hline year & 1993 & 1993 & 1993 & 1993 & 2000 & 2000 & 2000 & 2000 & 2015 & 2015 & 2015 & 2015 \\
\hline country & VAir/VAr & VAir/VAi & VAr/VAt & $L Q=I R C$ & VAir/VAr & VAir/VAi & VAr/VAt & $L Q=I R C$ & VAir/VAr & VAir/VAi & VAr/VAt & $L Q=I R C$ \\
\hline US & 0.0919 & 0.2982 & 0.2720 & 1.0963 & 0.0928 & 0.3289 & 0.3215 & 1.0229 & 0.0944 & 0.2837 & 0.2554 & 1.1109 \\
\hline $\mathrm{CN}$ & 0.0610 & 0.0179 & 0.0246 & 0.7275 & 0.0614 & 0.0256 & 0.0379 & 0.6772 & 0.0443 & 0.0813 & 0.1559 & 0.5214 \\
\hline$J P$ & 0.0852 & 0.1788 & 0.1760 & 1.0163 & 0.0961 & 0.1612 & 0.1522 & 1.0592 & 0.1051 & 0.0762 & 0.0616 & 1.2370 \\
\hline DE & 0.0635 & 0.0566 & 0.0747 & 0.7577 & 0.0877 & 0.0531 & 0.0550 & 0.9661 & 0.0923 & 0.0466 & 0.0429 & 1.0865 \\
\hline UK & 0.0915 & 0.0391 & 0.0358 & 1.0918 & 0.1093 & 0.0552 & 0.0458 & 1.2045 & 0.1114 & 0.0472 & 0.0360 & 1.3109 \\
\hline FR & 0.0920 & 0.0524 & 0.0478 & 1.0980 & 0.0967 & 0.0409 & 0.0384 & 1.0662 & 0.0963 & 0.0347 & 0.0306 & 1.1329 \\
\hline PL & 0.0877 & 0.0036 & 0.0034 & 1.0462 & 0.0892 & 0.0046 & 0.0047 & 0.9830 & 0.1039 & 0.0073 & 0.0060 & 1.2227 \\
\hline $\mathrm{CZ}$ & 0.0936 & 0.0016 & 0.0014 & 1.1176 & 0.1127 & 0.0022 & 0.0018 & 1.2425 & 0.1070 & 0.0030 & 0.0024 & 1.2590 \\
\hline $\mathrm{HU}$ & 0.0881 & 0.0014 & 0.0014 & 1.0516 & 0.1082 & 0.0015 & 0.0013 & 1.1927 & 0.1136 & 0.0019 & 0.0014 & 1.3372 \\
\hline SK & 0.0868 & 0.0005 & 0.0005 & 1.0360 & 0.1129 & 0.0007 & 0.0006 & 1.2443 & 0.1187 & 0.0016 & 0.0011 & 1.3974 \\
\hline LT & 0.0991 & 0.0003 & 0.0003 & 1.1827 & 0.1320 & 0.0005 & 0.0003 & 1.4549 & 0.1511 & 0.0009 & 0.0005 & 1.7783 \\
\hline LV & 0.2565 & 0.0006 & 0.0002 & 3.0617 & 0.1747 & 0.0004 & 0.0002 & 1.9254 & 0.1420 & 0.0006 & 0.0003 & 1.6718 \\
\hline EE & 0.1551 & 0.0003 & 0.0001 & 1.8511 & 0.1568 & 0.0003 & 0.0002 & 1.7286 & 0.1385 & 0.0004 & 0.0003 & 1.6300 \\
\hline VAi/VAt & $x$ & $x$ & $x$ & 0.0838 & $x$ & $x$ & $x$ & 0.0907 & $x$ & $x$ & $x$ & 0.0850 \\
\hline
\end{tabular}

Source: own processing 


\section{Ekonomie}

\section{Appendix 3: Export - Import (USD at current price in millions)}

\begin{tabular}{|c|c|c|c|c|c|c|c|c|}
\hline item & ICT goods & - export & ICT good & import & total & sport & total i & port \\
\hline year & 2000 & 2015 & 2000 & 2015 & 2000 & 2015 & 2000 & 2015 \\
\hline World & 999,908 & $1,947,707$ & $1,033,480$ & $2,111,422$ & $7,940,643$ & $20,951,483$ & $7,948,904$ & $20,559,230$ \\
\hline US & 156,670 & 141,752 & 218,859 & 318,419 & $1,073,922$ & $2,223,624$ & $1,451,263$ & $2,763,374$ \\
\hline $\mathrm{CN}$ & 44,135 & 607,559 & 45,454 & 394,496 & 297,561 & $2,429,294$ & 250,688 & $2,044,652$ \\
\hline$J P$ & 108,807 & 53,236 & 61,485 & 80,014 & 528,816 & 732,146 & 459,872 & 752,499 \\
\hline GE & 46,169 & 61,799 & 58,283 & 89,259 & 627,992 & $1,560,478$ & 627,023 & $1,307,658$ \\
\hline UK & 51,529 & 19,122 & 69,970 & 52,247 & 404,503 & 785,383 & 433,719 & 839,427 \\
\hline FR & 31,916 & 19,877 & 35,988 & 37,598 & 377,993 & 752,292 & 361,491 & 766,205 \\
\hline PL & 1,268 & 15,782 & 4,499 & 18,572 & 46,430 & 234,080 & 57,312 & 220,853 \\
\hline $\mathrm{CZ}$ & 1,334 & 21,278 & 3,118 & 21,993 & 35,893 & 153,914 & 37,624 & 142,325 \\
\hline $\mathrm{HU}$ & 7,231 & 11,658 & 6,482 & 11,418 & 34,915 & 110,947 & 36,709 & 100,388 \\
\hline SK & 391 & 12,495 & 764 & 10,947 & 14,207 & 81,126 & 14,666 & 78,995 \\
\hline LT & 182 & 1,003 & 266 & 1,438 & 5,124 & 31,483 & 5,862 & 31,612 \\
\hline LV & 16 & 1,324 & 209 & 1,410 & 3,256 & 15,884 & 3,835 & 16,271 \\
\hline EE & 967 & 1,656 & 659 & 1,763 & 4,809 & 18,093 & 5,033 & 17,185 \\
\hline
\end{tabular}

Source: own processing using UNCTADSTAT data 


\title{
Abstract
}

\section{AT THE THRESHOLD OF THE FOURTH INDUSTRIAL REVOLUTION: WHO GETS WHO LOSES}

\author{
Ivana Kraftová, Iveta Doudová, Radim Miláček
}

At the beginning of the second decade of the 21st century, the Fourth Industrial Revolution based on the digitization of production processes, more precisely connecting the virtual world to the real world began. The aim of this article is to present the results of the research that focused on comparing the positions of the selected group of countries at the threshold of the Fourth Industrial Revolution in terms of their performance and competitiveness.

The analysis is aimed at 13 countries - the six largest economies of the world and seven economies of the former Soviet bloc - from 1993 to 2015 using the localization quotient and index of regional concentration of the industry on the basis of gross added value, supplemented by the SHADE model, the Balassa index and evaluating the comparative advantage of countries in the area of ICT.

The research defines the position pattern of countries for the manufacturing and ICT industries. It cannot be said that the differences in localization, resp. the concentration of the industries surveyed were determined by the size of the economy or its membership of traditional market economies. Exportability in ICT goods positively evaluates those economies that have managed to increase their positive Balassa index over time, resp. to get from its negative values to positive ones.

The beginning of the Fourth Industrial Revolution is an unrepeatable moment of human history, just as it was with the First, Second and Third Industrial Revolutions. The one who knows and is able to accept, use and multiply the supporting trends is the one who gains.

Key Words: The Fourth Industrial Revolution, localization and concentration of industry, manufacturing, ICT, position pattern, ICT goods, comparative advantage, performance, competitiveness.

JEL Classification: F63, L69, O33.

DOI: 10.15240/tul/001/2018-3-002 